\title{
On-The-Job Training Performance of Technology Students in One of the State Universities in the Philippines
}

\author{
Karlo S. Sira, Ed. D. \\ Gerardo F. Araque, MTE \\ Associate Professor \\ Iloilo Science and Technology University \\ Philippines
}

\begin{abstract}
This study aimed to determine the profile and performance of the on-the-job training (OJT) students in the different training areas as evaluated by their respective OJT centres based on the evaluation standard set by the Department of Labor and Employment (DOLE) and the University OJT Manual. The researchers used the survey method and the data collected from the purposively selected samples were processed and qualitatively analyzed. This paper presents the results of the evaluation study which gave valued information and suggests appropriate actions related to the status of the technology students taking OJT and their performance in the workplace.
\end{abstract}

Keywords: Bachelor in Industrial Technology, Technology courses, on-the-job training, performance, evaluation, Higher Education Institution,

\section{Introduction}

OJT is everybody's job nowadays; it is a conglomeration of all the competencies acquired by the students during their stay in the college or university. Alli (2008) claimed that education and training provide individuals with the necessary theoretical and practical knowledge required to carry out their trade or occupation successfully and to fit into the working environment to become a professional and productive worker. It is part of a college or university curriculum that aims to orient and train students about the work and their future career. Also, it is essential not only to teach students their chosen career but to show students the reality of working. Consequently, the Department of Labor and Employment Manual (DOLE) (2015) stipulated that OJT is a training program designed to immerse students in a work environment relevant to their courses as they desire to acquire productivity, knowledge, and respect in the workplace.

\section{Is the OJT program necessary to find a dream job?}

There is a greater chance to find a dream job once a student has undergone the OJT program. Bukaliya (2012) confirmed that OJT provided students with a smooth transition from the academic world to the working environment. Higher education "is not a real-life experience," it will teach the necessary knowledge and skills that are necessary for the chosen field of work so that after graduation, an individual will have a higher chance of finding a better job (Michiya, 2010).

\section{Why is OJT necessary?}

The Commission of Higher Education (CHED) which is the official governing body of higher education institutions in the Philippines and the Executive Order No. 83, s. 2012, which is the "Institutionalization of the Philippine Qualification Framework (PQF)," mandated to set a minimum standard for programs and institutions of higher learning (section 8d) and to adopt national standards and levels for outcomes of education, maintain pathways and equivalencies as access to qualifications. One of the requirements of CHED is the OJT.

DOLE (2015) of the Philippine government stressed that OJT is a training program for students designed to immerse the students in a work environment relevant to their courses as they desire to acquire productivity in, knowledge on, and respect to the workplace. Besides, OJT programs are course requirements providing an opportunity to not only apply the theories, principles, and ideas learned in the academe but also enhance the technical knowledge, skills and attitudes of students towards work necessary for satisfactory job performance. 
It also serves as a venue where students earn experience in career positions relevant to their choice of academic degrees as well as open up their future career choices towards decent and gainful employment.

Therefore, the program outcomes are congruent to its competencies to the workplace that impact the society (CHED Handbook on Typology, 2012). Along with this, the ASEAN Quality Reference Framework (2015) calls for all Higher Education Institution (HEI) to support the quality framework for lifelong learning through quality qualifications systems for better employment, and greater job satisfaction. Sira (2016) in his study recommended revising competencies used in teaching the subjects offered under the Bachelor in Industrial Technology major in Architectural Drafting Technology Program of state universities and colleges.

Ideally, the academe and industry should work hand-in-hand for the OJT to make it useful and efficient. Parallel competencies are expected from the academe by the industry. The industry may give feedback and inputs on what is going on in the workplace.

\section{Iloilo Science and Technology University}

For more than a century of existence, ISAT U has been a constant provider of quality technologists in the country and abroad. These technologists are the students from the College of Industrial Technology (CIT) the top caliber in the field of technological knowledge and skills in the Region.

Under the R. A. 10595 (2013), an act converting Western Visayas College of Science and Technology into Iloilo Science and Technology University (ISAT U), the institution has shifted its paradigm from competency-based to outcome-based education. The University envisions itself as the leading university in Southeast Asia in 2030. It is committed to providing quality and relevant advanced education, higher technological, professional instruction and training in arts, sciences, education, architecture, engineering, agriculture, forestry, and other fields of study, thereby producing locally oriented, globally competitive and eco-friendly human resources.

OJT program is the main attraction of the technology programs of the CIT namely: Architectural Drafting; Construction, and Furniture and Cabinet Making. In this process, the students were sent to government and private OJT centres based not only in Iloilo City and Province but also in Metro Manila, to practice what they learned in the school and to hone their skills further there. As expected, the trainees perform the desired tasks assigned to them by their centers, and their performances are evaluated at the end of every semester of their stay in the center. The numerical rating given to them serves as a requirement for graduation; it also provides a baseline data on what particular aspects of their training need to be improved. Thus, the individual performances of the trainees provide the OJT supervisors, coordinators, and the whole CIT, the basis for addressing the status as to the strengths and weaknesses of the trainees.

OJT is one of the significant factors that lead to professionalism and productivity of a worker someday. Boakye (2014) claimed that in order to achieve such objectives, the trainees must have proper training with enough resource materials to read, develop a positive attitude towards work to keep them abreast with new developments and trends in technological education.

Valdez, Alcantara, Castillo, Pamintuan, \& Relos (2015) also affirmed that the OJT program of the university significantly contributes to the development of basic skills, thinking skills, personal qualities and competencies on resources, interpersonal, information, systems, and technology needed by tourism graduates as perceived by the graduates. Furthermore, Casiple (2014) discussed that the OJT in the Philippines HE provides tertiary students the opportunity to acquire practical knowledge, skills, and desirable attitude in reputable establishments or workplace in the country. OJT further enhance student's competencies towards work as well as the ability to work with their co-workers. It is also an avenue for their competitiveness and enrichment of the program leading for more opportunities toward network from experienced professionals, handle new challenges, and complex tasks or problems identify future career directions and become candidates for a future job opening.

The revision of the curriculum of the Bachelor of Industrial Technology (BIT) majoring technology courses in 2016 set another milestone in the quest for excellence to produce quality graduates in the field of technology. The one-year training provides the students the experience to master the actual job in the industry giving them the edge over other applicants in searching for the dream job. Determining the OJT performance of CIT students is essential as it offers useful data "necessary to determine the impact of the OJT programs that could be the basis of curricular discussion and immediate action on needed reforms and bring about the appropriate fitness between requirements of the industry and the offerings of the University" (Millington, 2015). 
The shop owners and industry supervisors can also use findings of the study as the basis for providing specific training to the OJT students for their professional growth. Hence, the researchers conducted this study.

\section{The Objectives of the Study}

This study aimed to determine the profile and performance of the on-the-job training (OJT) students in the different training areas as evaluated by their respective OJT centres based on the evaluation standard set by the Department of Labor and Employment (DOLE) and the University OJT Manual.

Specifically, the study is designed to

1. determine the profile of OJT students for AY 2016-2017;

2. identify the performance of the OJT students in the different areas of evaluation, and

3. determine if there are significant differences in the performances of the OJT students when grouped according to OJT centers.

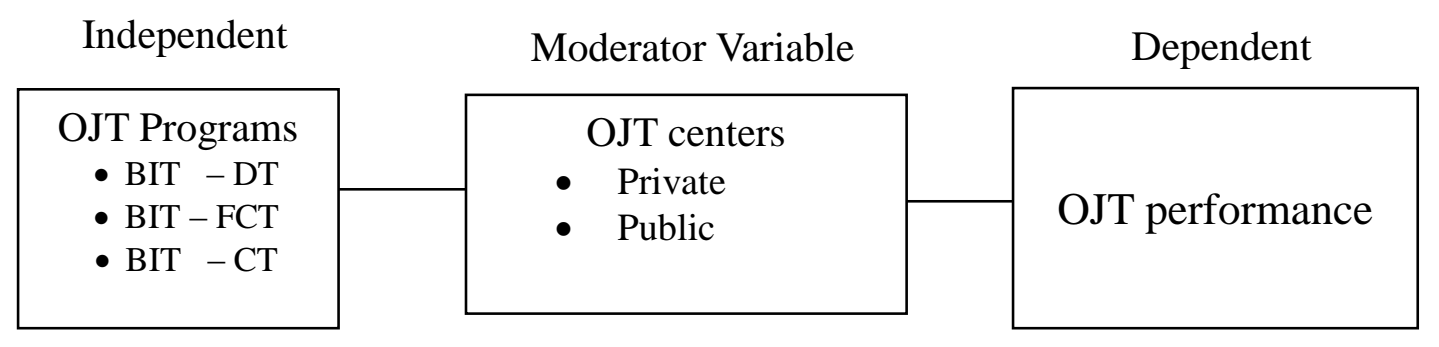

Figure 1: Conceptual Framework of the Study.

Figure 1 shows the graphical conceptual framework of the study. The OJT programs of the technology courses are the DT, FCT, and CT under the BIT curriculum. Students under these programs were deployed in the different OJT center (private and public) for one year and were rated by their direct supervisors using the established OJT questionnaire of the University.

\section{Methodology}

\section{Research Design}

This study used a descriptive survey covering the profile and the performance of the participants as evaluated by their direct supervisors. It includes the curriculum product evaluation as to the effectiveness, relevance, and adequacy of competencies, by determining how well the OJT students have achieved the goal of their respective programs as well as the applicability of these competencies in their respective centers.

\section{Respondents and Sampling Plan}

This study was designed to obtain both qualitative and quantitative data for the OJT students of the three technology courses and their supervisors of the centers from 44 participants (DT- 32, CT- 8, and FCT- 4) officially enrolled in the program were purposively selected and deployed in the different center in the City and province of Iloilo, Metro Manila, Cavite City, and Valenzuela City. Crossman (2018) pointed out that this type of sampling can be advantageous in situations when you need to reach a targeted sample quickly, and where sampling for proportionality is not the primary concern.

\section{Table 1: Distribution of the Respondents}

\begin{tabular}{|c|c|c|}
\hline \multirow[t]{2}{*}{ BIT Programs } & \multicolumn{2}{|c|}{ Total } \\
\hline & $\mathbf{n}$ & $\%$ \\
\hline Architectural Drafting Technology (DT) & 32 & 72.73 \\
\hline Construction Technology (CT) & 8 & 18.18 \\
\hline Furniture and Cabinet Making Technology (FCT) & 4 & 9.09 \\
\hline Total & 44 & 100.00 \\
\hline
\end{tabular}

\section{Instrument and Data Gathering Procedure}

In order to obtain the qualitative and quantitative data about their OJT performance and feedback on the competencies of the technology curriculum, this study utilized an established university evaluation questionnaire for OJT students patterned after the format of the DOLE Manual (2015). The instrument consists of twelve (12) areas and four (4) sub-categories per area of evaluation. 
The areas were (1) ability to follow the instruction; (2) appearance; (3) attitude towards work; (4) expense consciousness; (5) job skills; (6) cooperation; (7) attendance and punctuality; (8) public relations; (9) dependability; (10) quality of the work; (11) work area; and (12) observance of the rules.

At the end of the semester the shop owners, presidents, immediate supervisors, and managers rated the trainees using the numeral value with two as the lowest and eight as the highest. An open-ended question is prepared for them to give their feedback on the program as well on the overall performance of the trainees. Moreover, the evaluation report served as their final grade. The 44 accomplished questionnaires gathered on time despite the difficulty and hardships. The data from the gathered accomplished forms were encoded, summarized, tabulated, processed, analyzed and interpreted quantitatively and qualitatively.

\section{Data Analysis}

The data gathered in this study were computer-processed using Statistical Package for Social Science (SPSS) Version 22. In analyzing the results, the researcher used the frequency count and percentage, mean, and standard deviation for descriptive analysis and the t-test for inferential analysis. The mean was used to determine the onthe-job training performance of the BIT major in DT, CT, and FCT of the CIT of ISAT U. The obtained mean ratings were interpreted and described using the following scales and descriptions:

\section{Rating Scale for Interpreting the Mean}

\begin{tabular}{|c|c|c|}
\hline Range & Description & Interpretation \\
\hline $6.75-8.00$ & Very High & Very competent \\
\hline $4.50-6.74$ & High & Competent \\
\hline $3.25-4.49$ & Low & Slightly Competent \\
\hline $2.00-3.24$ & Very Low & Not Competent \\
\hline
\end{tabular}

The standard deviation was used to indicate the homogeneity or heterogeneity of the respondents concerning their responses. The t-test for independent samples was used to determine the significance of the difference between means of groups in two categories such as OJT centers where they were assigned. All hypotheses tested at the .05 level of significance.

\section{Results and Discussion}

\section{The Profile of the Respondents as to Program and Sex}

Table 2.1 shows that as to sex, 29 of the 44 trainees were male and 15 were female. Among the males, 17 were from DT, 8 from CT, and 4 from FCT. All 15 females were from the DT program. This findingconforms to the study of Sira, Celda, Sobrepeña, \& Valenciana, (2016) that the BIT curriculum is a male-dominated one. In the DT curriculum, however, a slight difference in numbers existed between male and female respondents.

Table 2.1: Profile of the OJT Trainees by Programs and Sex

\begin{tabular}{|l|c|c|c|c|c|c|}
\hline \multirow{2}{*}{ Course } & \multicolumn{4}{|c|}{ Sex } & \multicolumn{2}{|c|}{ Total } \\
\cline { 2 - 5 } & \multicolumn{2}{|c|}{ Male } & \multicolumn{2}{c|}{ Female } & \multicolumn{2}{|c|}{. } \\
\cline { 2 - 6 } & $\mathbf{n}$ & $\mathbf{\%}$ & $\mathbf{n}$ & $\mathbf{\%}$ & $\mathbf{n}$ & $\mathbf{\%}$ \\
\hline DT & 17 & 53.13 & 15 & 46.88 & 32 & 100.00 \\
\hline CT & 8 & 100.00 & 0 & 0.00 & 8 & 100.00 \\
\hline FCT & 4 & 100.00 & 0 & 0.00 & 4 & 100.00 \\
\hline Total & $\mathbf{2 9}$ & 65.91 & $\mathbf{1 5}$ & 34.09 & $\mathbf{4 4}$ & 100.00 \\
\hline
\end{tabular}

\section{The Profile of the Respondents as to Programs and Training Centers}

The table shows a total of 44 students assigned for OJT training in the different offices/training centers in the province of Iloilo, city of Iloilo and Metro Manila of which 13 assigned in public and 31 assigned in the private centers. Of the 32 DT students, 13 assigned in the public centers and 19 assigned in the private centers, while all the $8 \mathrm{CT}$ and 4 FCT students assigned in the private centers. That of the two centres more trainees were assigned in private centers since there are more offices in private than in the public sector that needs the specialization of the BIT like AutoCAD operators, building construction workers, or furniture makers. 
Table 2.2: Profile of the OJT Trainees by Programs and Training Centers

\begin{tabular}{|c|c|c|c|c|c|c|}
\hline \multirow[t]{3}{*}{ Course } & \multicolumn{4}{|c|}{ OJT Center } & \multirow{2}{*}{\multicolumn{2}{|c|}{ Total }} \\
\hline & \multicolumn{2}{|c|}{ Public } & \multicolumn{2}{|c|}{ Private } & & \\
\hline & $\mathbf{n}$ & $\%$ & $\bar{n}$ & $\%$ & $\mathbf{n}$ & $\%$ \\
\hline DT & 13 & 40.63 & 19 & 59.38 & 32 & 100.00 \\
\hline CT & 0 & 0.00 & 8 & 100.00 & 8 & 100.00 \\
\hline FCT & 0 & 0.00 & 4 & 100.00 & 4 & 100.00 \\
\hline Total & 13 & 29.55 & 31 & 70.45 & 44 & 100.00 \\
\hline
\end{tabular}

\section{OJT Competence of the Respondents as a Whole}

Table 3.1 shows that all of the competencies of the OJT students were rated "very high" by their training center supervisors particularly in the work area with a mean 7.91, while job skills havethe lowest mean of 7.50. It is evident that the work areas were kept outstandingly neat and clean by the OJT trainees all the time, as they are learning additional skills not related to their jobs but still essential and needed in the workplace. This result is similar to the findings of Nebril (2016) that the work engagement and level of OJT performance in drafting activities in Miagao, Iloilo, was "high," and that stronger linkages between ISAT U and industries involved should be strengthened to improve the school-industry tie-up and the training of students further. Meaning, the institutionalized competencies of the OJT defined the kind of performance the trainees acquired, and that supervisors and coordinator should strive hard to improve the OJT performance of the technician students of their field of specialization in order to make the technician curriculum more relevant to the emerging needs of industries. Furthermore, the supervisors and coordinator should continuously visit the industries in the service area of the university through a supervisor/ coordinator-industry attachment program.

\section{Table 3.1: Competence of the OJT Students as Rated by Supervisors} When Trainees Grouped According to Training Centers

\begin{tabular}{|l|c|c|c|}
\hline Competencies & Mean & Desc & sd \\
\hline $\begin{array}{l}\text { Ability to follow the } \\
\text { instruction }\end{array}$ & 7.77 & VH & 0.64 \\
\hline Appearance & 7.77 & VH & 0.64 \\
\hline Attitude towards work & 7.68 & VH & 0.74 \\
\hline Expense consciousness & 7.68 & VH & 0.86 \\
\hline Job skills & $\mathbf{7 . 5 0}$ & VH & $\mathbf{0 . 8 8}$ \\
\hline Cooperation & 7.73 & VH & 0.69 \\
\hline Attendance and punctuality & 7.59 & VH & 0.92 \\
\hline Public relation & 7.73 & VH & 0.69 \\
\hline Dependability & 7.64 & VH & 0.89 \\
\hline Quality of the work & 7.55 & VH & 0.95 \\
\hline Work area & $\mathbf{7 . 9 1}$ & VH & $\mathbf{0 . 4 2}$ \\
\hline Observance of the rules & 7.82 & VH & 0.58 \\
\hline Mean (overall) & 7.70 & VH & 0.57 \\
\hline
\end{tabular}

Legend: VH=Very High

\section{OJT Competence of OJT Students When Grouped According to Training Centers}

Table 3.2 shows that when respondents grouped according to training centers, the trainees in the private centers had the higher ratings than those in the public centers in the following areas: ability to follow the instruction, appearance, attitude towards work, cooperation, attendance and punctuality, public relation, and dependability. On the other hand, trainees in the public centers were rated higher than those in the private sectors in job skills, quality of the work, work area, and observance of the rules. They had the same ratings as to expense consciousness. Overall, the trainees in the public centers had a higher rating which implies that they were more competent than their private counterpart. 
Table 3.2: Competence of the OJT Students as Rated by Supervisors When Trainees Grouped According to Training Centers

\begin{tabular}{|l|l|l|l|l|l|c|}
\hline \multirow{2}{*}{ Competencies } & \multicolumn{3}{|c|}{ Public } & \multicolumn{3}{c|}{ Private } \\
\cline { 2 - 7 } & Mean & Desc & sd & Mean & Desc & sd \\
\hline Ability to follow the instruction & 7.76 & VH & 0.66 & 7.79 & VH & 0.63 \\
\hline Appearance & 7.76 & VH & 0.66 & 7.79 & VH & 0.63 \\
\hline Attitude towards work & 7.60 & VH & 0.82 & 7.79 & VH & 0.63 \\
\hline Expense consciousness & 7.68 & VH & 0.95 & 7.68 & VH & 0.75 \\
\hline Job skills & 7.76 & VH & 0.66 & 7.16 & VH & 1.01 \\
\hline Cooperation & 7.68 & VH & 0.75 & 7.79 & VH & 0.63 \\
\hline Attendance and punctuality & 7.52 & VH & 1.05 & 7.68 & VH & 0.75 \\
\hline Public relation & 7.68 & VH & 0.75 & 7.79 & VH & 0.63 \\
\hline Dependability & 7.68 & VH & 0.95 & 7.58 & VH & 0.84 \\
\hline Quality of the work & 7.60 & VH & 1.00 & 7.47 & VH & 0.90 \\
\hline Work area & 7.92 & VH & 0.40 & 7.89 & VH & 0.46 \\
\hline Observance of the rules & 7.92 & VH & 0.40 & 7.68 & VH & 0.75 \\
\hline Mean (overall) & 7.71 & VH & 0.62 & 7.67 & VH & 0.51 \\
\hline
\end{tabular}

\section{Differences in Competence of OJT Trainees When Grouped According to Training Centers}

The t-test for independent samples revealed that overall, the performances of the two groups did not differ from each other $(\mathrm{t}=0.220, \mathrm{p}=0.823)$; thus no rejection of the null hypothesis was made. However, a significant difference found in the competencies of trainees regarding job skills $(t=2.377, p=.022)$. Since the probability value is less than the 0.05 level of significance, a rejected on the hypothesis of no difference in the competencies of OJT students in public and private training centers as to job skills was considered. The public training center trainees were perceived to be more 'competent in the job skills compared to the private. Overall, both centers believed in the very high performance of the trainees and agreed that these trainees would become assets of their centers because the academe has equipped them with the necessary knowledge, skills, and attitudes needed in the workplace in the future. Table 3.2 shows the result.

Table 3.3: t-test Results for Differences in Competence of OJT Students as Rated by Training Center Supervisors When Trainees Grouped According to Centers

\begin{tabular}{|c|c|c|c|c|c|c|}
\hline Competencies & Centers & Mean & Mean Diff & $\mathbf{t}$ & df & $\mathbf{p}$ \\
\hline \multirow[t]{2}{*}{ Ability to follow the instruction } & Public & 7.76 & \multirow[t]{2}{*}{-0.03} & \multirow[t]{2}{*}{-0.149} & \multirow[t]{2}{*}{42} & \multirow[t]{2}{*}{0.882} \\
\hline & Private & 7.79 & & & & \\
\hline \multirow[t]{2}{*}{ Appearance } & Public & 7.76 & \multirow[t]{2}{*}{-0.03} & \multirow[t]{2}{*}{-0.149} & \multirow[t]{2}{*}{42} & \multirow[t]{2}{*}{0.882} \\
\hline & Private & 7.79 & & & & \\
\hline \multirow[t]{2}{*}{ Attitude towards work } & Public & 7.60 & \multirow[t]{2}{*}{-0.19} & \multirow[t]{2}{*}{-0.838} & \multirow[t]{2}{*}{42} & \multirow[t]{2}{*}{0.407} \\
\hline & Private & 7.79 & & & & \\
\hline \multirow[t]{2}{*}{ Expense consciousness } & Public & 7.68 & \multirow[t]{2}{*}{0.00} & \multirow[t]{2}{*}{-0.016} & \multirow[t]{2}{*}{42} & \multirow[t]{2}{*}{0.987} \\
\hline & Private & 7.68 & & & & \\
\hline \multirow[t]{2}{*}{ Job skills } & Public & 7.76 & \multirow[t]{2}{*}{0.60} & \multirow[t]{2}{*}{2.377} & \multirow[t]{2}{*}{42} & \multirow[t]{2}{*}{0.022} \\
\hline & Private & 7.16 & & & & \\
\hline \multirow[t]{2}{*}{ Cooperation } & Public & 7.68 & \multirow[t]{2}{*}{-0.11} & \multirow[t]{2}{*}{-0.514} & \multirow[t]{2}{*}{42} & \multirow[t]{2}{*}{0.61} \\
\hline & Private & 7.79 & & & & \\
\hline \multirow{2}{*}{ Attendance and punctuality } & Public & 7.52 & \multirow[t]{2}{*}{-0.16} & -0.58 & 42 & 0.565 \\
\hline & Private & 7.68 & & & & \\
\hline Public relation & Public & 7.68 & -0.11 & -0.514 & 42 & 0.61 \\
\hline & Private & 7.79 & & & & \\
\hline Dependability & Public & 7.68 & 0.10 & 0.369 & 42 & 0.714 \\
\hline & Private & 7.58 & & & & \\
\hline Quality of the work & Public & 7.60 & 0.13 & 0.432 & 42 & 0.668 \\
\hline & Private & 7.47 & & & & \\
\hline Work area & Public & 7.92 & 0.03 & 0.195 & 42 & 0.847 \\
\hline & Private & 7.89 & & & & \\
\hline Observance of the rules & Public & 7.92 & 0.24 & 1.344 & 42 & 0.186 \\
\hline & Private & 7.68 & & & & \\
\hline Overall & Public & 7.71 & 0.04 & 0.220 & 42 & 0.823 \\
\hline & Private & 7.67 & & & & \\
\hline
\end{tabular}




\section{Competence of the OJT Students When Grouped According to Sex}

When grouped according to sex, the performances of both and female trainees described as very high which means that both groups were very competent. The males were higher than the females in almost all areas of evaluation except in "cooperation" where the females were rated higher than the male. Although the performances of the two groups were very high, the university, particularly those who implement the OJT program, should still look for ways on how to enhance the training of students (Valdez, Alcantara, Castillo, Pamintuan, \& Relos, 2015) with particular concerns on the presented indicators with the lowest mean for each skill or competency. Presumably, it can be concluded that they are familiar with the activities done in the workplace but not on what particular skills needed to do the job result Table 3.4 shows the result.

Table 3.4: Competence of the OJT Students as Rated by Supervisors When Trainees Grouped According to Sex

\begin{tabular}{|l|l|l|l|l|l|c|}
\hline \multirow{2}{*}{ Competencies } & \multicolumn{6}{|c|}{ Sex } \\
\cline { 2 - 8 } & \multicolumn{3}{|c|}{ Male } & \multicolumn{3}{c|}{ Female } \\
\cline { 2 - 8 } & Mean & Desc & sd & Mean & Desc & sd \\
\hline Ability to follow the instruction & 7.79 & VH & 0.62 & 7.73 & VH & 0.70 \\
\hline Appearance & 7.86 & VH & 0.52 & 7.60 & VH & 0.83 \\
\hline Attitude towards work & 7.72 & VH & 0.70 & 7.60 & VH & 0.83 \\
\hline Expense consciousness & 7.79 & VH & 0.82 & 7.47 & VH & 0.92 \\
\hline Job skills & 7.72 & VH & 0.70 & 7.07 & VH & 1.03 \\
\hline Cooperation & 7.66 & VH & 0.77 & 7.87 & VH & 0.52 \\
\hline Attendance and punctuality & 7.66 & VH & 0.94 & 7.47 & VH & 0.92 \\
\hline Public relation & 7.86 & VH & 0.52 & 7.47 & VH & 0.92 \\
\hline Dependability & 7.79 & VH & 0.82 & 7.33 & VH & 0.98 \\
\hline Quality of the work & 7.72 & VH & 0.88 & 7.20 & VH & 1.01 \\
\hline Work area & 7.93 & VH & 0.37 & 7.87 & VH & 0.52 \\
\hline Observance of the rules & 7.86 & VH & 0.52 & 7.73 & VH & 0.70 \\
\hline Overall Mean & 7.78 & VH & 0.68 & 7.53 & VH & 0.82 \\
\hline
\end{tabular}

\section{Differences in Competence of the OJT Students When Grouped According to Sex}

The t-test for differences in means between sexes revealed no significant difference ( $p>.05$ ); hence Ho was not rejected. However, a significant difference was found in the competencies of trainees in terms of job skills $(\mathrm{p}<.05)$, hence, of no difference in the competencies as to job skills of the male and female OJT students. In job skills, the males were more competent than the females. Table 3.5 shows the5result.

Table 3.5: t-Test Results for Differences in Competence of the OJT Students as Rated by Training Centre Supervisors When Trainees Grouped According to Sex

\begin{tabular}{|c|c|c|c|c|c|c|}
\hline Competencies & Sex & Mean & Mean Diff & $\mathbf{t}$ & df & $\mathbf{p}$ \\
\hline \multirow{2}{*}{ Ability to follow the instructions } & Male & 7.79 & \multirow[t]{2}{*}{0.06} & \multirow[t]{2}{*}{0.29} & \multirow[t]{2}{*}{42} & \multirow[t]{2}{*}{0.774} \\
\hline & Female & 7.73 & & & & \\
\hline \multirow{2}{*}{ Appearance } & Male & 7.86 & \multirow{2}{*}{0.26} & \multirow[t]{2}{*}{1.293} & \multirow[t]{2}{*}{42} & \multirow[t]{2}{*}{0.203} \\
\hline & Female & 7.60 & & & & \\
\hline \multirow{2}{*}{ Attitude towards work } & Male & 7.72 & \multirow{2}{*}{0.12} & \multirow{2}{*}{0.523} & \multirow[t]{2}{*}{42} & \multirow{2}{*}{0.604} \\
\hline & Female & 7.60 & & & & \\
\hline \multirow{2}{*}{ Expense consciousness } & Male & 7.79 & \multirow[t]{2}{*}{0.33} & \multirow{2}{*}{1.205} & \multirow[t]{2}{*}{42} & \multirow[t]{2}{*}{0.235} \\
\hline & Female & 7.47 & & & & \\
\hline \multirow{2}{*}{ Job skills } & Male & 7.72 & \multirow[t]{2}{*}{0.66} & \multirow{2}{*}{2.500} & \multirow[t]{2}{*}{42} & \multirow[t]{2}{*}{0.016} \\
\hline & Female & 7.07 & & & & \\
\hline \multirow{2}{*}{ Cooperation } & Male & 7.66 & \multirow[t]{2}{*}{-0.21} & \multirow[t]{2}{*}{-0.957} & \multirow[t]{2}{*}{42} & \multirow[t]{2}{*}{0.344} \\
\hline & Female & 7.87 & & & & \\
\hline \multirow{2}{*}{ Attendance and punctuality } & Male & 7.66 & \multirow[t]{2}{*}{0.19} & 0.638 & 42 & 0.527 \\
\hline & Female & 7.47 & & & & \\
\hline Public relation & Male & 7.86 & 0.40 & 1.84 & 42 & 0.073 \\
\hline Public relation & Female & 7.47 & & & & \\
\hline Denendahility & Male & 7.79 & 0.46 & 1.654 & 42 & 0.106 \\
\hline Dependabinty & Female & 7.33 & & & & \\
\hline Ouality of the work & Male & 7.72 & 0.52 & 1.775 & 42 & 0.083 \\
\hline Quanty or the work & Female & 7.20 & & & & \\
\hline & Male & 7.93 & 0.06 & 0.476 & 42 & 0.637 \\
\hline work area & Female & 7.87 & & & & \\
\hline Observance of the rules & Male & 7.86 & 0.13 & 0.692 & 42 & 0.493 \\
\hline & Female & 7.73 & & & & \\
\hline & Male & 7.78 & 0.25 & 1.384 & 42 & 0.174 \\
\hline Uverall & Female & 7.53 & & & & \\
\hline
\end{tabular}




\section{Competence of the OJT Students When Grouped According to Course}

When grouped according to Course, Table 3.6 shows that the CT trainees were rated the highest followed by FCT and DT although the performance of the three groups were all very high overall. The CT and the FCT groups were higher than the DT group in every area evaluate except in "cooperation" where CT had the highest rating followed by the DT and the FCT. Bukaliya (2012) stressed that through OJT or internship program supervisors of the centers proved how competent the trainees are in applying the theories learned in the classroom with an understanding of issues relevant to their particular areas of study. The relevance of pre-service training of PNU, curricular program competencies are notable in Gines (2014). Hence, the more knowledgeable and skillful the students are, the better they perform in the center.

Table 3.6: Competence of the OJT Students as Rated by Supervisors When Trainees Grouped According to Course

\begin{tabular}{|l|c|c|c|c|c|c|c|c|c|}
\hline \multirow{3}{*}{\multicolumn{1}{|c|}{ Competencies }} & \multicolumn{9}{|c|}{ Course } \\
\cline { 2 - 12 } & \multicolumn{3}{|c|}{ DT } & \multicolumn{3}{c|}{ CT } & \multicolumn{3}{c|}{ FCT } \\
\cline { 2 - 11 } & Mean & Desc & sd & Mean & Desc & sd & Mean & Desc & sd \\
\hline Ability to follow the instruction & 7.69 & VH & 0.74 & 8.00 & VH & 0.00 & 8.00 & VH & 0.00 \\
\hline Appearance & 7.69 & VH & 0.74 & 8.00 & VH & 0.00 & 8.00 & VH & 0.00 \\
\hline Attitude towards work & 7.56 & VH & 0.84 & 8.00 & VH & 0.00 & 8.00 & VH & 0.00 \\
\hline Expense conscious & 7.56 & VH & 0.98 & 8.00 & VH & 0.00 & 8.00 & VH & 0.00 \\
\hline Job skills & 7.31 & VH & 0.97 & 8.00 & VH & 0.00 & 8.00 & VH & 0.00 \\
\hline Cooperation & 7.69 & VH & 0.74 & 8.00 & VH & 0.00 & 7.50 & VH & 1.00 \\
\hline Attendance and punctuality & 7.44 & VH & 1.05 & 8.00 & VH & 0.00 & 8.00 & VH & 0.00 \\
\hline Public relation & 7.63 & VH & 0.79 & 8.00 & VH & 0.00 & 8.00 & VH & 0.00 \\
\hline Dependability & 7.5 & VH & 1.02 & 8.00 & VH & 0.00 & 8.00 & VH & 0.00 \\
\hline Quality of the work & 7.38 & VH & 1.07 & 8.00 & VH & 0.00 & 8.00 & VH & 0.00 \\
\hline Work area & 7.88 & VH & 0.49 & 8.00 & VH & 0.00 & 8.00 & VH & 0.00 \\
\hline Observance of the rules & 7.75 & VH & 0.67 & 8.00 & VH & 0.00 & 8.00 & VH & 0.00 \\
\hline Overall Mean & 7.59 & VH & 0.84 & 8.00 & VH & 0.00 & 7.96 & VH & 0.08 \\
\hline
\end{tabular}

The ANOVA result in Table 3.7shows that the differences in the mean ratings of the three groups were not significant ( $p>.05$ ) hence, the hypothesis of no difference among the means regarding the performances of the three groups of OJT trainees was not rejected.

Table 3.7: ANOVA Results for Differences in Competencies of OJT Students as Rated by Training Center Supervisors When Trainees Grouped According to Course

\begin{tabular}{|c|c|c|c|c|c|c|}
\hline Competencies & Sources of Variation & SS & df & MS & $\mathbf{F}$ & Sig. \\
\hline \multirow[t]{3}{*}{ Ability to follow the instruction } & Between Groups & .852 & 2 & .426 & 1.035 & .364 \\
\hline & Within Groups & 16.875 & 41 & .412 & & \\
\hline & Total & 17.727 & 43 & & & \\
\hline \multirow[t]{3}{*}{ Appearance } & Between Groups & .852 & 2 & .426 & 1.035 & .364 \\
\hline & Within Groups & 16.875 & 41 & .412 & & \\
\hline & Total & 17.727 & 43 & & & \\
\hline \multirow[t]{3}{*}{ Attitude towards work } & Between Groups & 1.670 & 2 & .835 & 1.565 & .221 \\
\hline & Within Groups & 21.875 & 41 & .534 & & \\
\hline & Total & 23.545 & 43 & & & \\
\hline \multirow[t]{3}{*}{ Expense consciousness } & Between Groups & 1.670 & 2 & .835 & 1.146 & .328 \\
\hline & Within Groups & 29.875 & 41 & .729 & & \\
\hline & Total & 31.545 & 43 & & & \\
\hline \multirow[t]{3}{*}{ Job skills } & Between Groups & 4.125 & 2 & 2.063 & 2.929 & .065 \\
\hline & Within Groups & 28.875 & 41 & .704 & & \\
\hline & Total & 33.000 & 43 & & & \\
\hline \multirow[t]{3}{*}{ Cooperation } & Between Groups & .852 & 2 & .426 & .879 & .423 \\
\hline & Within Groups & 19.875 & 41 & .485 & & \\
\hline & Total & 20.727 & 43 & & & \\
\hline \multirow[t]{3}{*}{ Attendance and punctuality } & Between Groups & 2.761 & 2 & 1.381 & 1.671 & .201 \\
\hline & Within Groups & 33.875 & 41 & .826 & & \\
\hline & Total & 36.636 & 43 & & & \\
\hline \multirow[t]{3}{*}{ Public relation } & Between Groups & 1.227 & 2 & .614 & 1.290 & .286 \\
\hline & Within Groups & 19.500 & 41 & .476 & & \\
\hline & Total & 20.727 & 43 & & & \\
\hline \multirow[t]{3}{*}{ Dependability } & Between Groups & 2.182 & 2 & 1.091 & 1.398 & .259 \\
\hline & Within Groups & 32.000 & 41 & .780 & & \\
\hline & Total & 34.182 & 43 & & & \\
\hline \multirow[t]{3}{*}{ Quality of the work } & Between Groups & 3.409 & 2 & 1.705 & 1.969 & .153 \\
\hline & Within Groups & 35.500 & 41 & .866 & & \\
\hline & Total & 38.909 & 43 & & & \\
\hline \multirow[t]{3}{*}{ Work area } & Between Groups & .136 & 2 & .068 & .373 & .691 \\
\hline & Within Groups & 7.500 & 41 & .183 & & \\
\hline & Total & 7.636 & 43 & & & \\
\hline \multirow[t]{3}{*}{ Observance of the rules } & Between Groups & .545 & 2 & .273 & .799 & .457 \\
\hline & Within Groups & 14.000 & 41 & .341 & & \\
\hline & Total & 14.545 & 43 & & & \\
\hline \multirow[t]{3}{*}{ Mean (overall) } & Between Groups & 1.385 & 2 & .693 & 2.268 & .116 \\
\hline & Within Groups & 12.523 & 41 & .305 & & \\
\hline & Total & 13.909 & 43 & & & \\
\hline
\end{tabular}




\section{Conclusions}

This study is a collaboration of efforts of the OJT supervisors handling the three technology courses under the CIT of ISAT U. The result of the study is significantly useful in addressing the needs of the OJT program and identifying its strengths and weaknesses, and the relevance of its competencies to the labor market both locally and internationally. Based on the findings of the study the following conclusions were drawn:

- Technology courses of the CIT are male-dominated ones. The participants are male, young, single, and training in the private centers located in Iloilo City.

- The performances of the OJT students as rated by training center supervisors were "very high."

- There was a significant difference in the performance of trainees regarding job skills when grouped according to centers; trainees in the public training centers were perceived to be better in job skills compared to the trainees in the private training centers.

\section{Recommendations}

Based on the findings and conclusions of this study, the researchers recommend the following:

- Intensify the OJT program by providing incentives to trainees with outstanding performance in the assigned centers.

- Strengthen the linkage program of the OJT through industry partners whose standards competencies are of the same in the ASEAN countries.

- Improve the competencies of the OJT program of the BIT curriculum to meet the demand of the ASEAN 2015 integration.

- Institutionalize the system-wide study of the status of the OJT program every two years including other technology courses with the industry supervisors as participants of the study.

\section{Acknowledgment}

Profound gratitude and appreciation are extended to the Administration of ISAT U under the leadership of its president Dr. Raul F. Muyong.

\section{References}

Alli, B. O. (2008). Fundamental Principles of Occupational Health and Safety. International Labour Organization - Geneva. 35. Retrieved December 22, 2017, from https://www.senate. gov.ph/republicacts/ra\% 2010595.pdf

ASEAN Qualifications Reference Framework (2015). Retrieved December 23, 2017, from http://asean.org/aseaneconomiccommunity/sectoral-bodies-under-the-purviewof-aem/services/asean-qualificationsreferenceframework/

Boakye, O. G. (2014). On-The-Job Training as a Basis for Enhancing the Performance of Newly-Employed Teachers at the Ejisu-Juaben Municipality of Ashanti Region of Ghana (C) 2014 Department of Managerial Science. Department of Managerial Science, Kwame Nkrumah University of Science and Technology. Retrieved December 22, 2017, from ir.knust.edu.gh/ xmlui/ handle/ 123456789/ 7658? Show $=$ full

Bukaliya, R. (2012). The Potential Benefits and Challenges of Internship Programmes in an ODL Institution: A Case For The Zimbabwe Open University. International Journal on New Trends in Education and Their Implications January, February, March 2012 Volume: 3 Issue: 1 Article: 13 ISSN 1309-6249. Retrieved December 23, 2017, from http://ijonte.org/FileUpload/ks63207/File/13.bukaliya.pdf

Casiple, R. (2014). OJT Program: The most effective form of job training. The Daily Guardian June 17, 2014 issue. Retrieved May 6, 2018, from https://thedailyguardian.net/option/ojt-program-the-most-effectiveform-of-job-training/

CHED Memorandum Order (2012). CHED Memorandum Order No. 46, series of 2012. Policy-Standard to Enhance Quality Assurance (QA) in Philippines Higher Education through an Out-comes-Based and Typological Based QA. Retrieved January 6, 2018, from http://ched.gov.ph/cmo-46-s-2012/.

Crossman, A. (2018). Understanding Purposive Sampling. Retrieved July 2, 2017, from https://www.thoughtco.com/purposive-sampling-3026727 
De Chavez, K. J. V., Lumanglas, J.L., Rondilla, K. M., Salcedo, J. A., \& Caiga, B. T. (2016). On-the-Job Training and Academic Performance of Mechanical Engineering Students in One Academic Institution in the Philippines. Asia Pacific Journal of Academic Research in Social Sciences Vol. 1 No.1, 54-63 November 2016 ISSN 2545-904X. Retrieved August 2, 2017, from http://research.lpubatangas.edu.ph/wpcontent/uploads/2016/12/APJARSS-2016.1.06.pdf

Department of Labor and Employment (2015). On-the-Job Training Manual: Ensuring Effective on-the-job Training, Region 6, Iloilo City, Philippines.

Executive Order No. 83 (2012). Institutionalization of the Philippine Qualification Framework. Retrieved from http://www.offcialgazette.gov.ph/2012/10/01/executive-order-no-83-s-2012/.

Gines, A. C. (2014). Tracer Study of PNU Graduates. American International Journal of Contemporary Research. (4) 3, 95-96.

Michiya, M. (2010) University Education Is Necessary. www.studymoda.com/essays/University-EducationIsNecessary-396146.html Retrieved December 23, 2012, from www.english-test.net/forum/ftopic55084.html

Nebril, R. M. (2016). Work Engagement and on-the-job performance in Drafting Activities of Bachelor in Industrial Technology Students in ISAT U-Miagao Campus. Unpublished Master's Thesis, Iloilo Science and Technology University, La Paz, Iloilo City, Philippines.

R. A. 10595 (2013). An act converting Western Visayas College of Science and Technology into Iloilo Science and Technology University (ISAT U), La Paz, Iloilo City, Philippines.

Sira, K. S. (2016). Development and Validation of Standard Competencies in Architectural Drafting Technology Program. The Normal Lights, 10(2), $1-29$.

Sira, K. S., Celda, M. A. M., Sobrepeña, A. C., \& Valenciana, D.S.O. (2016). The Bachelor of Industrial Technology Major in Architectural Drafting Technology Program Tracer Study. Unpublished Departmental Research, Iloilo Science and Technology University, La Paz, Iloilo City, Philippines.

Valdez, E. J. C, Alcantara, S. S. B., Castillo, R. C., Pamintuan, C. A., \& Relos, J. G. (2015). Contributions of Onthe-Job Training Program to the Skills, Personal Qualities, and Competencies of Tourism Graduates. Asia Pacific Journal of Multidisciplinary Research, Vol. 3, No. 4, November 2015 Part II. Retrieved December 5, 2017, from https://www.researchgate.net/publication/288807944/download

WVCST BOT Resolution 12/21/2007-84 \& ACCORESOLUTION NO. 18D (2014). Policies and Standards for Bachelor of Science and Industrial Technology program.

\section{Bio note:}

KARLO S. SIRA is an associate professor of Iloilo Science and Technology University, La Paz, Iloilo City, Philippines, 5000; karlo_sira@yahoo.com. His research focuses on architectural drafting technology and industrial education. Presently, he is the head of the Drawing and Drafting Technology Department and at the same time OJT supervisor.

GERARDO F. ARAQUE is an associate professor of Iloilo Science and Technology University, La Paz, Iloilo City, Philippines, 5000, gfaraque@yahoo.com.ph. His line of interest is on electronics technology and industrial education. A former OJT coordinator of the College of Industrial Technology and OJT supervisor. 


\section{The Instrument}

\begin{tabular}{|c|c|l|l|}
\hline \multirow{2}{*}{$\begin{array}{c}\text { Republic of the Philippines } \\
\text { ILOILO SCIENCE AND TECHNOLOGY } \\
\text { UNIVERSITY } \\
\text { La Paz, Iloilo City }\end{array}$} & $\begin{array}{l}\text { Department } \\
:\end{array}$ & On-the-Job Training \\
\cline { 2 - 3 } & $\begin{array}{l}\text { Document } \\
\text { Code: }\end{array}$ & QF-OJT-03 \\
\cline { 2 - 4 } & ON-THE-JOB TRAINING EVALUATION REPORT & $\begin{array}{l}\text { Rev. No.: } \\
\text { Effective } \\
\text { Date: }\end{array}$ & $\begin{array}{l}01 \\
\text { November 18, 2015 }\end{array}$ \\
\hline
\end{tabular}

Name of Student Trainee:

Course, Year \& Section:

School Term:

Major:

Training Center and Address:

School Year:

Training Period: From

to

No. of Hours Completed:

Instruction: There are twelve (12) areas of evaluation and four (4) sub-categories per area. Please evaluate the trainee by checking (/) before the phrase that best described the trainee. The rating used a 4-point rating scale per category, eight is the highest (top), and two is the lowest (below).

\section{ABILITY TO FOLLOW THE INSTRUCTION}

Use initiative in interpreting and (8)

Usually, follow instruction with no difficulty

Follows instructions with some

difficulty

Needs repeated detailed instruction

\section{APPEARANCE}

Exceptionally neat and appropriately

Neat and appropriately dressed

Satisfactorily dressed

Sometimes neglectful of appearance and dress

\section{ATTITUDE TOWARDS WORK}

Takes a keen interest in the training and takes the initiative to learn Shows interest in training and has desire to learn

Has some interest in the training Supervision

Shows little interest or enthusiasm for the training

\section{EXPENSE CONSCIOUSNESS}

Extremely careful in using materials and equipment

Uses sound judgment in using materials and equipment for good work Takes average care in using materials and equipment

Careless about equipment and materials

\section{ATTENDANCE AND PUNCTUALITY}

Never been absent or late without following instructions good cause

(6)

Seldom being absent or late without good cause

Occasionally being absent or late

(2) Frequently absent or late

\section{PUBLIC RELATION}

Extremely tactful and understanding in dressed dealing with all types of customers Usually poised, courteous and tactful in dealing with people Tries to please costumers Sometimes lacks poised and in different to others

\section{DEPENDABILITY}

Meets all obligation unfailingly without supervision

Meets obligation with very little supervision

Meets obligation careful

Sometimes fails in the obligation even under careful supervision

\section{QUALITY OF THE WORK}

Has an aptitude for doing neat, accurate work and exceeding the requirements Does more than the required amount

Does the normal amount of acceptable work

Does less than the required amount of satisfactory work 
JOB SKILLS

Possesses all essential skills and

Information

Has an above average command of the essential skills and related information Has an acceptable command of the skills and related information

Lacks essential skills and related information

\section{COOPERATION}

Always cooperates eagerly and cheerfully Usually cooperates eagerly and cheerfully Cooperates willingly when ask Cooperates reluctantly
WORK AREA

Keeps work area outstandingly neat and efficiently organized Takes pride in the appearance and arrangement of the work area

Follows good housekeeping rules

Allows work area to become disorganized and untidy

OBSERVANCE OF THE RULES

Always observes company rules

Seldom disregards company rules

Observes most of the company rules Frequently neglects company rules

\section{OVER-ALL EVALUATION OF STUDENT-TRAINEE}

Total Points: Equivalent Grade:

Grade/Point Equivalent

$\begin{array}{llllll}94-96 & 1.0 & 73-75 & 1.7 & 52-54 & 2.4 \\ 91-93 & 1.1 & 70-72 & 1.8 & 49-51 & 2.5 \\ 88-90 & 1.2 & 67-69 & 1.9 & 46-48 & 2.6 \\ 85-87 & 1.3 & 64-66 & 2.0 & 43-45 & 2.7 \\ 82-84 & 1.4 & 61-63 & 2.1 & 40-42 & 2.8 \\ 79-81 & 1.5 & 58-60 & 2.2 & 37-39 & 2.9 \\ 76-78 & 1.6 & 55-57 & 2.3 & 24-36 & 3.0\end{array}$

Remarks:

(Industry Training Center Officer/ Supervisor)

Date:

Indorsed by:

OJT Supervisor

OJT Coordinator
Department Head

Approved:

\section{Dean}

